\author{
食道音声の客観的評価法 \\ 一母音の音質を対象として一 \\ 大森 孝一・庄司 和彦・藤田 修治* \\ 福島 英行 ・ 児嶋 久剛
}

\title{
Objective Evaluation of Esophageal Voice Quality
}

\author{
Koichi Omori, Kazuhiko Shoji, \\ Hideyuki Fukushima and Hisayoshi Kojima \\ (Kyoto University) \\ Shuji Fujita \\ (Osaka Red Cross Hospital)
}

\begin{abstract}
A method of objectively evaluating the voice quality of esophageal speech is described in this paper. We used the vowel $/ \mathrm{a} /$ of 27 esophageal speakers as a voice sample.

As judged from perceptual impressions, the voice samples were ranked by the paired comparison method. Acoustic parameters such as maximum phonation time, fluctuation of intensity and periodicity of vibration were examined. We compared the perceptual ranking and those three parameters by non-parametric statistical methods. There was a significant correlation between the last two parameters and the perceptual ranking. Low fluctuation (less than $10 \mathrm{~dB}$ in $500 \mathrm{msec}$ from the voice onset) and periodic vibration were assumed to be a standard for the good voice quality of esophageal speech.
\end{abstract}

Key words: esophageal voice, objective evaluation, fluctuation of intensity, periodic vibration

はじめに

食道発声の目標は会話によるコミュニケーシ

ョンであるが，その習得は容易ではなく充分な 会話能力が得られない症例がみられる。 その理 由としては，(1)声が続かない，(2)声が小さい， (3)声質が悪いなどがあり，乙れらの要因の客観 的評価法として，従来(1)には最大発声持続時間 が，(2)には音圧が用いられてきた。しかし(3)の
声の質については食道音声の音質が一般に極め て悪いため, 従来の音声評価法では不充分であ った.

そこで著者らは，音声の基本である母音のう ち/a／を用い，聴覚印象之音声学的指標之の 関係から食道音声の客観的評価基準となる指標 を見いだそうとした. 


\section{対象}

食道発声者27例（男性25例，女性 2 例）の音 声サンプルを調べた。年齢は45〜79歳, 喉摘後 の期間は 5 カ月〜 18年 5 カ月であった.

\section{方 法}

母音 /a／を無関位発声させて DAT に録音 し，乙れをローパスフィルター, $\mathrm{AD}$ 変換器を 通してコンピュータに取り込み，以下のような 分析を行なった（図1）.

1) 聴覚印象の順位付け

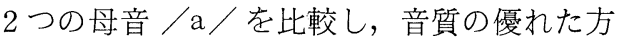
に 1 点, 劣る方に -1 点, 同程度の場合には 両者 0 点とし，乙れを全ての組合せ 351 通りに ついてランダムに調べ，各症例でとの得点を集 計した。聴覚判定は耳鼻科医 3 名, Speech Therapist 2 名の 計 5 名で行い，得点合計の高い 順に聴覚印象の良い順とした。この際発声持続 時間が聴覚印象に影響しないように起声部より $500 \mathrm{msec}$ を切取った音声を用いた。詳細は既 報1のとおりである.

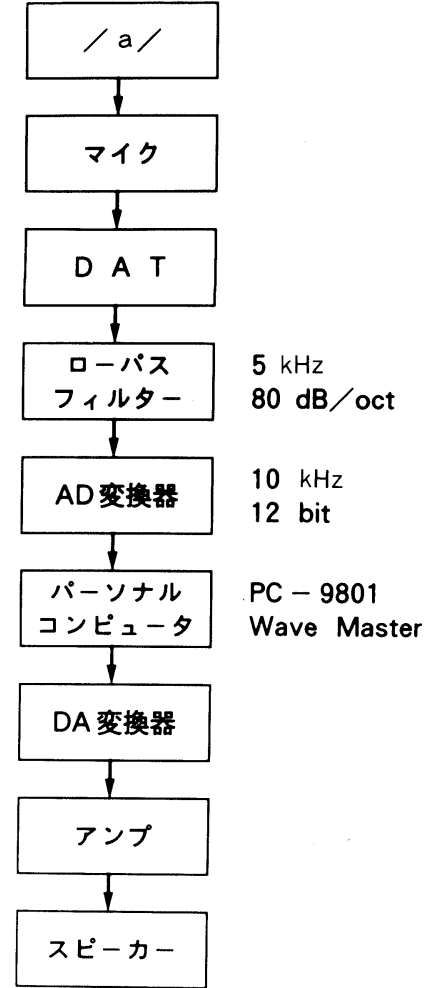

図1 ブロックダイヤグラム

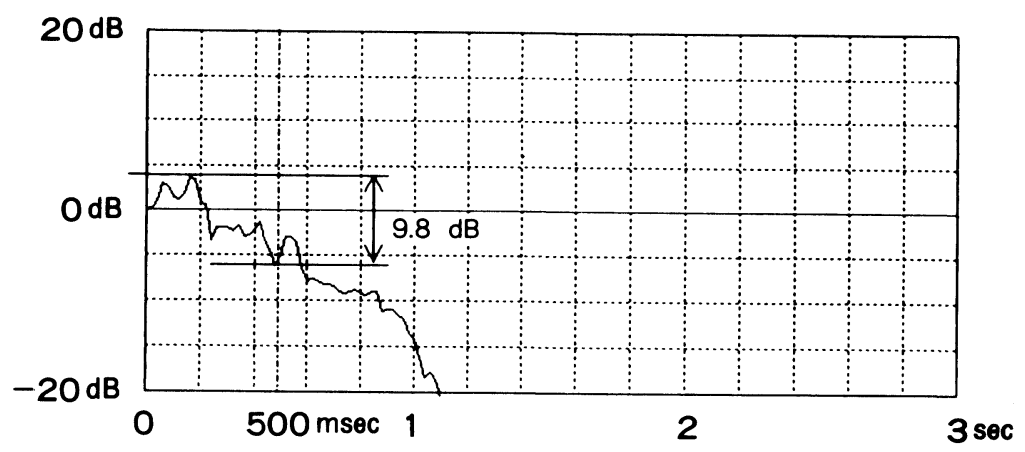

$$
\begin{aligned}
& P\left(\text { 実効音圧) }=\sqrt{\frac{1}{N} \sum_{k=1}^{N} A_{k}^{2}} \quad \begin{array}{l}
A_{k}: \text { 振幅 } \\
N=500(50 \mathrm{msec})
\end{array}\right. \\
& F(t)(\text { 音圧変動 })=20 \log \frac{P_{t}}{P_{1}}(d B) \quad \begin{array}{l}
P_{t}: t \text { 時の実効音圧 } \\
P_{1}: \text { 起声時の実効音压 }
\end{array}
\end{aligned}
$$

図 2 音圧変動

音圧の経時的変化を示す.

起声時から $500 \mathrm{msec}$ までの音压の最大值と最小值の差を変動 幅とした. 本症例の音圧変動幅は $9.8 \mathrm{~dB}$ である. 
2 ) 音声学的指標

(a)最大発声持続時間

食道発声では発声持続時間が極めて短く, ス トップウオッチによる手動計測では䛊差が大き いので，ディスプレイ上に表示した音声波形の 始点から終点までの時間を測定した。

(b)音圧変動

起声時の実効音圧を基準値とした音圧レベル の経時的変化を音圧変動として表した．今回は 起声時より $500 \mathrm{msec}$ までの音压の最大值と最 小值の差, すなわち変動幅を音圧変動の指標と した（図 2 ).

(C)振動の周期性

音声波形を高速フーリエ変換（2048ポイント， Hanning 空) で周波数分析し, 調和成分が明確 に認められた例を周期性有り (図 $3 \mathrm{~A}$ ), 雑音成 分が多く調和成分が不明確な例を周期性無しと した（図 3 B).

A

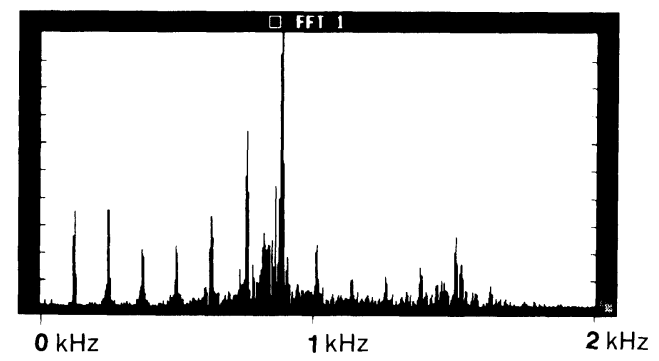

B

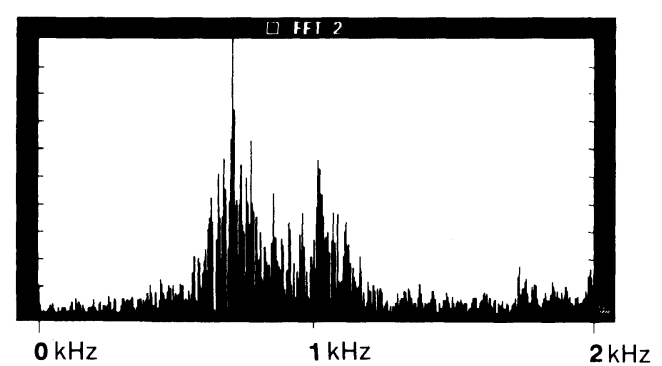

図 3 周波数分析

A：調和成分が明確に認められる。 (60歳, 喉摘後 7 年 6 力月経過)

$\mathrm{B}$ : 杂隹音成分が多く調和成分が不明確である. (74歳，喉摘後10年 2 力月経過)
3 ) 聴覚印象之音声学的指標の相関関係

聴覚印象順位は離散量であるからノンパラメ トリックな統計学的手法が妥当と考え，聴覚印 象之最大発声持続時間, 及び聴覚印象之音圧 変動幅之の相関は Spearman の順位相関関数 を，聴覚印象之振動の周期性の有無との相関は Wilcoxon $\mathrm{T}$ 検定を用いて調べた.

\section{結果}

1 ) 聴覚印象順位

聴覚印象判定の総合得点は +97 点から -112 点化分布し，同順位が 3 組あった（表 1 ）.

2 ) 音声学的指標

(a)最大発声持続時間： $428 \mathrm{msec} \sim 2507 \mathrm{msec}$ に分布し，平均 $1167 \mathrm{msec}$ であった.

表 1 聴覚印象順位と音声学的指標

\begin{tabular}{|c|c|c|c|}
\hline $\begin{array}{c}\text { 聴覚印象 } \\
\text { (位) }\end{array}$ & $\begin{array}{c}\text { MPT } \\
(\mathrm{msec})\end{array}$ & $\begin{array}{c}\text { 音王変動幅 } \\
(\mathrm{d} B)\end{array}$ & 周期的振動 \\
\hline 1 & 2507 & 6.3 & + \\
\hline 2 & 852 & 7.6 & + \\
\hline 3 & 1126 & 9.8 & + \\
\hline 4 & 751 & 3 & + \\
\hline 4 & 1560 & 7.4 & + \\
\hline 6 & 1117 & 6.5 & + \\
\hline 7 & 989 & 6.1 & + \\
\hline 8 & 789 & 6 & + \\
\hline 9 & 482 & 21.9 & - \\
\hline 10 & 1028 & 11.1 & + \\
\hline 10 & 1538 & 7.7 & + \\
\hline 12 & 1213 & 9.2 & + \\
\hline 13 & 2087 & 5.7 & + \\
\hline 14 & 1468 & 9.1 & + \\
\hline 15 & 584 & 8.6 & - \\
\hline 16 & 2058 & 12.6 & + \\
\hline 17 & 439 & 29 & - \\
\hline 18 & 2356 & 8.2 & + \\
\hline 19 & 1072 & 18.7 & + \\
\hline 20 & 1042 & 15.4 & + \\
\hline 21 & 689 & 12.8 & - \\
\hline 22 & 1264 & 5.4 & + \\
\hline 23 & 992 & 13.4 & - \\
\hline 24 & 755 & 9.5 & - \\
\hline 24 & 968 & 7.2 & - \\
\hline 26 & 1397 & 9.3 & - \\
\hline 27 & 428 & 19.7 & - \\
\hline
\end{tabular}


(b)音圧変動幅: $3 \mathrm{~dB} \sim 29 \mathrm{~dB}$ 亿分布し, 平均 10. $6 \mathrm{~dB}$ であった.

(C)振動の周期性 : 周期的振動を認めた例が18 例, 認めなかった例が 9 例であった.

以上を表 1 亿示す.

3 ) 聴覚印象之各音声学的指標の相関関係

聴覚印象順位と最大発声持続時間との関係は Spearman の順位相関関数 rs $=0.198$ (片側 5 \%での臨界値 0.323）で相関関係を認めなかっ た.

聴覚印象順位と音圧変動幅では, Spearman の順位相関関数 $\mathrm{rs}=0.428$ で相関関係が認めら れ(危険率 $5 \%$ ), 変動幅が小さいほど聴覚印 象な良好であった。ささら音圧変動幅の度数分 布を見ると $10 \mathrm{~dB}$ 以内に全症例の $2 / 3$ (18例) が含まれたので（図 4)，10 dBで分けて，聴覚 印象之の関係をみたところ，音圧変動幅が 10 $\mathrm{dB}$ 以内の群が $10 \mathrm{~dB}$ を越える群に比べて有意 に聴覚印象が良好であった (Wilcoxon $\mathrm{T}$ 検定 危険率 $5 \%$ ).

聴覚印象順位と振動の周期性の有無では Wilcoxon $\mathrm{T}$ 検定で両群間に有意差がみられ(危険 率 $1 \%$ ), 周期性の有る群が聴覚印象良好であ った。

\section{考按}

食道発声で会話可能になるまでの期間につい て, 佐藤 ${ }^{2)}$ は 6 力月程度としており, 約 6 力月 〜 年の練習で日常会話ができなければ，他の
発声法に切り替えるのが妥当と考えられてい $ろ^{2) 3}$. 食道発声の会話能力の評価法は, 会話 の流暢性や他人との意志疎通の程度を見る主観 的方法があり ${ }^{4)}$, , 一方, 佐藤 ${ }^{2)}$ は, 発声持続時 間, 食道発声係数 (空気摄取時間/発声時間), 最強音音圧, ピッチの変化, 1 回空気攝取によ る発語音節数, 文章の明瞭度, 雑音の程度など の測定值をての指標としており，Williams $ら^{6)}$ あ音質, 基本周波数, 音圧, 話す速さ, わかり やすさ, 会話中の外観, 雑音, 意志疎通の程度 などを客観的なデータとして取り上げている。 また, Schutte らつは1回空気摂取による発語音 節数, 最大発声持続時間, 音圧の dynamic range, 最大音圧について, 食道発声の評価基準を作成 している.

前述のように食道発声の良不良を決定する因 子は，(1)声の持続性，(2)声の大きさ，(3)音質に 整理でき，(1)は駆動部（攝取した空気），(2)は 駆動部（攝取した空気）及び振動部（下咽頭・ 食道粘膜), (3)は振動部 (下咽頭・食道粘膜) が 主に関与していると考えられる. (3)の評価に関 しては, 著者らは一対比較法を用いた食道音声 の客観的聴覚判定法により, 音質と他のパラメ ーターとの相関関係を調べたが1), 本稿では母 音 $/ \mathrm{a} /$ 聴覚印象之音声学的指標との相関関 係を調べ，食道音声の客観的評価基準となるも のを検討した。

その結果, 聴覚印象と最大発声持続時間との

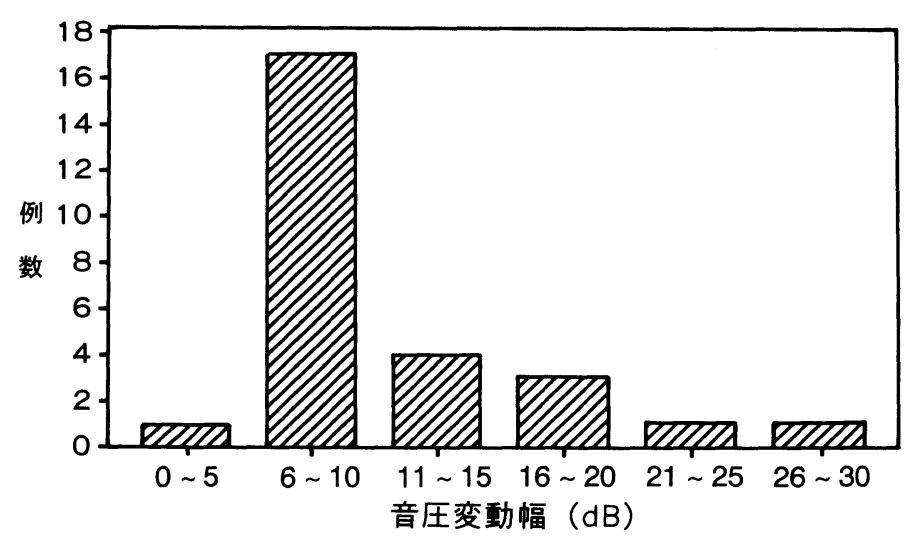

図 4 音圧変動幅の度数分布 
間には相関がみられず，食道内への空気捸取量 が多く発声持続時間の長い例が必ずし屯良好な 音声には聞こえないととがわかった。音圧の経 時的変化については，変動幅が小さいほど聴覚 印象は良好であり，送気量が定常的で安定した 粘膜振動が得られるほど良好な音声に聞こえる と考えられた．さらに音圧変動幅 $10 \mathrm{~dB}$ 以内の 群が $10 \mathrm{~dB}$ を越える群に比べて有意に聴覚印象 良好であったてとから，音質の評価基準を 10 $\mathrm{dB}$ 以内の変動幅に設定することが妥当と考元 られた。 また，当然のことながら周期的振動を 示す群が聴覚印象良好であり，下咽頭・食道粘 膜の規則的振動がみられる例の音声が良好に聞 こえるあのと考えられた．以上のことから食道 音声の単母音に関して臨床的に基準を引くなら ば，音圧変動幅が $10 \mathrm{~dB}$ 以内，振動の周期性が ある例の音質が良好といえる。

食道音声の母音の評価については, Imaizumi ら ${ }^{8)}$ が各代用音声の母音の音質を比較し聴取者 の聴覚心理的尺度を分析しており，また，食道 音声の基本周波数およびそのゆらぎ，音圧，発 声持続時間など音声学的指標を調べた報告はみ られるが779)，今回の結果から音圧の経時的変 化と振動の周期性に関する因子が聴覚印象と相 関したことから，乙れらの因子も食道音声の客 観的評価の一指標となると考えられた。本評価 法は特に，粘膜振動の状態を把握することがで きる点で有用であると考えられた。

\section{まとめ}

食道発声者 27 名の母音 $/ a /$ 音質と音声学 的指標の関係を分析し以下の結果を得た。

1. 音質と最大発声持続時間とは無関係であ った.

2. 音質と音圧変動, 及び振動の周期性とは 相関し, 音圧変動幅は $10 \mathrm{~dB}$ 以内, 振動の周期 性が有る例が音質良好であった。

3. これらの基準は食道発声の振動状態の把 握に有用で，食道音声の客観的評価の一指標に なると考えられた。
稿を終えるにあたり，御校閲頂きました京都大学医 学部耳鼻咽喉科学教室本庄 踇教授に深謝致します.

本論文の要旨は第33回音声言語医学会で口演した。

\section{参考文献}

$1 ）$ 大森孝一, 庄司和彦, 福島英行, 他 : 食道音声の 聴覚判定法一母音の音質を対象として一. 耳鼻臨 床 $82: 967 \sim 970,1989$.

2 ）佐藤武男：喉頭癌一その基礎之臨床一. 金原出版, 東京, 1986.

3 ）大森孝一, 庄司和彦, 本庄 踇：喉頭全摘後の音 声リハビリテーション．耳鼻臨床 $82 ：$ 99〜102, 1989.

4 ) 高藤次夫：食道発声の訓練法。耳喉 $38 ： 189$ 195, 1966.

5 ）小宮山荘太郎, 広戸幾一郎, 武馬成人, 他 : 無喉 頭者の発声方法の適示に関する研究. 耳鼻 20 : 113 121, 1974.

6 ) Williams SE and Watson JB : Speaking proficiency variations according to method of alaryngeal voicing. Laryngoscope $97: 737 \sim 739,1987$.

7 ) Schutte HK, Bors EFM, Boer GHA, et al : Evaluation of speech with and without a "Groningen Type" voice button. Speech Restoration Via Voice Prostheses (ed by Herrmann IF). pp 135 138, Springer-Verlag, Berlin, Heiderberg, 1986.

8) Imaizumi S, Boku S, Koike $Y$, et al : Evaluation of alaryngeal voice quality by nonparametric procedures. Auris-Nasus-Larynx (Tokyo) $10: 49 \sim$ 60, 1983.

9) Robbins J, Fisher HB, Blom EC, et al : A comparative acoustic study of normal esophageal and tracheoesophageal speech production. J Speech Hear Disord $49:$ 202 210, 1984.

$\left(\begin{array}{l}\text { 原稿受付 }: \text { 平成 } 2 \text { 年 } 2 \text { 月 } 1 \text { 日 } \\ \text { 原稿採択 : 平成 } 2 \text { 年 } 2 \text { 月 } 9 \text { 日 } \\ \text { 別刷請求先 }: \text { 大森孝一 } \\ \text { 干 } 606 \text { 京都市左京区聖護院川原町 } 54 \\ \text { 京都大学医学部耳鼻四喉科学教室 }\end{array}\right)$

